\title{
Social determinants of health associated with childhood accidents at home: An integrative review
}

\author{
Determinantes sociais da saúde associados a acidentes domésticos na infância: uma revisão integrativa
}

Determinantes sociales de la salud asociados con accidentes domésticos en la infancia: una revisión integradora

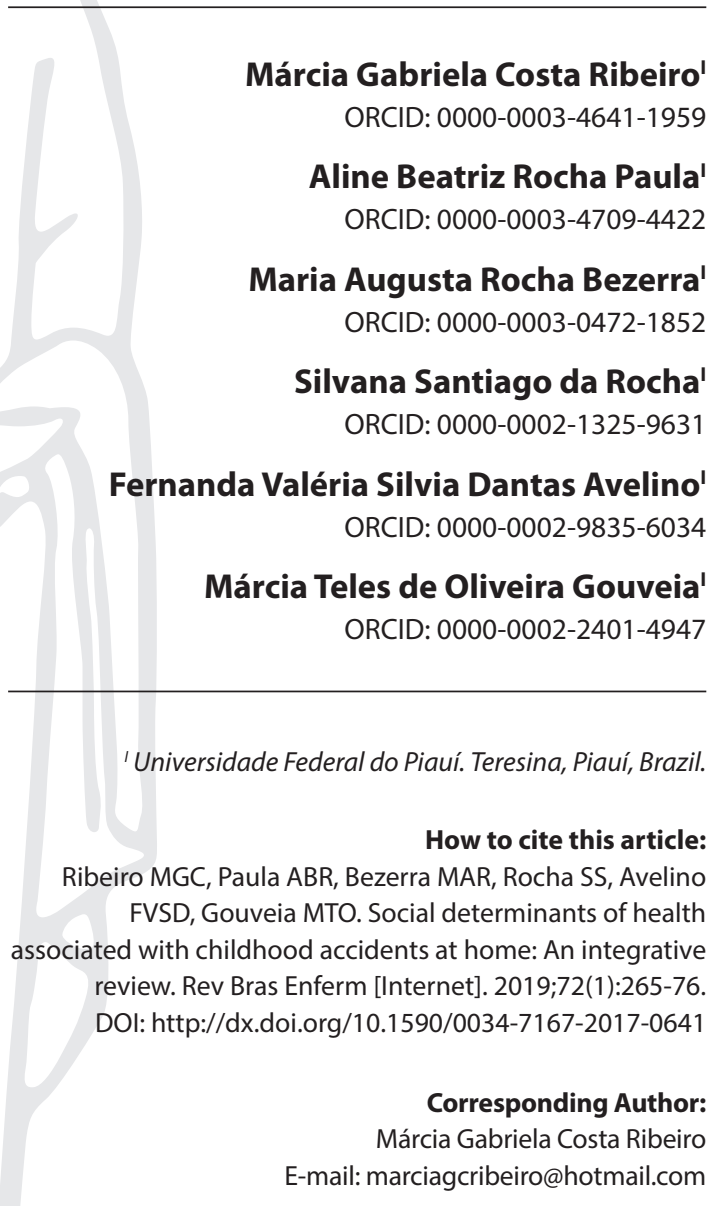

Submission: 09-23-2017

Approval: $12-07-2018$

\section{ABSTRACT}

Objective: to analyze the factors associated with childhood accidents at home according to the levels of the social determinants of health. Method: integrative review of the literature, with research in databases CINAHL, LILACS and PubMed, with the following main descriptors: child; social determinants of health; accidentes, home. We included 31 studies that related the social determinants of health and childhood accidents, in English, Portuguese and Spanish. Results: the proximal determinants identified were: age and sex of children, and ethnicity. Among the intermediate determinants of health, parental behavior, related to the supervision of an adult, prevailed. Parental employment and socioeconomic status were identified as distal determinants. Conclusion: the age and sex of the child, besides direct supervision, were the determinants most associated with accidents. The distal determinants should be better studied because their relation with the occurrence of domestic accidents has not been sufficiently clarified.

Descriptors: Child; Social Determinants of Health; Population Groups; Dangerous Behavior; Accidents at Home.

\section{RESUMO}

Objetivo: analisar os fatores associados aos acidentes domésticos na infância segundo os níveis dos determinantes sociais da saúde. Método: revisão integrativa da literatura, com pesquisa em bases de dados CINAHL, LILACS e PubMed, com os seguintes descritores principais:child; social determinants of health; accidentes, home. Foram incluídos 31 estudos que relacionaram os determinantes sociais da saúde e acidentes domésticos na infância, em inglês, português e espanhol. Resultados: os determinantes proximais identificados foram: idade e sexo das crianças, e etnia. Dentre os intermediários, prevaleceram o comportamento parental, relacionado à supervisão de um adulto. $\mathrm{O}$ emprego dos pais $\mathrm{e}$ a situação socioeconômica foram identificados como determinantes distais. Conclusão: a idade e o sexo da criança, além da supervisão direta, foram os determinantes mais associados aos acidentes. Os determinantes distais devem ser mais bem estudados, pois sua relação com a ocorrência dos acidentes domésticos não se mostrou suficientemente esclarecida.

Descritores: Criança; Determinantes Sociais da Saúde; Grupos Populacionais; Comportamento Perigoso; Acidentes Domésticos.

\section{RESUMEN}

Objetivo: analizar los factores asociados a los accidentes domésticos en la infancia según los niveles de los determinantes sociales de la salud. Método: la revisión integradora de la literatura, con investigación en bases de datos CINAHL, LILACS y PubMed, con los siguientes descriptores principales: child; social determinants of health; accidentes, home. Se incluyeron 31 estudios relacionados con los determinantes sociales de la salud y accidentes domésticos en la infancia, en inglés, portugués y español. Resultados: los determinantes proximales identificados fueron: edad y sexo de los niños, y etnia. Entre los intermediarios, prevalecieron el comportamiento parental, relacionado a la supervisión de un adulto. El empleo de los padres y su situación socioeconómica fueron identificados como determinantes distales. Conclusión: la edad y el sexo de los niños, además de la supervisión directa, fueron los determinantes más asociados con los accidentes. Los determinantes distales deben ser más bien estudiados, pues su relación con la ocurrencia de los accidentes domésticos no se mostró suficientemente esclarecida.

Descriptores: Niños; Determinantes Sociales de la Salud; Grupos Poblacionales; Comportamiento Peligroso; Accidentes Domésticos. 


\section{INTRODUCTION}

Accidents at Home $(\mathrm{AH})$ in childhood represent an important global health problem ${ }^{(1-2)}$, because they are potentially serious but still underestimated ${ }^{(3)}$. It is verified that these injuries have contributed significantly to raise the infant morbidity and mortality rates, since in addition to being closely related to the stage of childhood itself, they also often reflect the lack of protective capacity of the family and the lack of knowledge of the numerous risk factors that permeate the daily life of children ${ }^{(4)}$.

Among the major types of $\mathrm{AH}$ with children, there is a high prevalence of falls, burns and intoxications. From these accidents, the World Health Organization estimated that, in 2004, roughly 830,000 children under 18 would die worldwide as a result of an unintentional injuries. However, recent community-based studies conducted by the United Nations Children's Fund (UNICEF) suggested that the number could be much higher ${ }^{(2)}$.

In Brazil, a study aimed at analyzing the profile of emergency care due to accidents and violence involving children under 10 in 2011 showed that of the 7,224 emergency services among children from zero to nine years old, 7,043 (97.5\%) were victims of accidents and 181 (2.5\%) of violence. Of the total number of children, $19.5 \%$ were one year old and $42.7 \%$ two to five years old. Most of the events happened at home (67.4\%), and this place was statistically associated with accidents ${ }^{(5)}$.

This situation indicates the need to know the determinants and conditions for the occurrence of $\mathrm{AH}$ with children, which relate to a wide network of social and cultural factors of individuals and their families ${ }^{(6)}$, such as lack of knowledge of families, non-cultural preventive measures, habits that favor the occurrence of accidents, poor supervision of children, unsafe domestic environments with the presence of dangerous products and materials, indiscriminate delegation of tasks incompatible with the child's age, access to guns, lack of more effective laws and lack of communication ${ }^{(7)}$.

Considering these facts, the broader context of health, which allows a more in-depth analysis of the risks for the occurrence of $\mathrm{AH}$ with children, should consider the complexity of the determinants of health. They are the conditions in which people are born, grow, live, work and age, shaped by the distribution of financial resources and power, as well as general resources, at the local, national and global levels ${ }^{(8)}$. Therefore, this set of factors must be organized and analyzed from the perspective of the Social Determinants of Health (SDH), to characterize the individuals' particularities and reflect their insertion in a space-time, as conditioning factors of AH in childhood ${ }^{(9)}$.

Based on this understanding, further studies are necessary to determine the risk factors for the occurrence of unintentional injury deaths ${ }^{(10)}$, since the detailed knowledge of these factors, in a preventive approach, is essential to allow progress to control accidents ${ }^{(7)}$. In addition, previous reviews of the literature analyzed the risk factors for $\mathrm{AH}$ in childhood but did not list them from the perspective of SDH. Therefore, knowing the elements/factors that determine the life and health conditions of children victims of $\mathrm{AH}$ will provide more appropriate actions, which may intervene to transform certain SDHs that represent negative aspects to the health of this population in this context ${ }^{(9)}$.

\section{OBJECTIVE}

To analyze the factors associated with childhood accidents at home according to the levels of the social determinants of health.

\section{METHOD}

This is an integrative review of the literature. For its elaboration, the following steps were adopted: identification/formulation of the problem; literature search/collection of data; evaluation of data; analysis of the findings of the articles included in the review; and presentation and interpretation of results ${ }^{(11)}$.

In the first step, the available knowledge about the relationship between social determinants of health and the occurrence of $\mathrm{AH}$ in childhood was listed. Thus, this study was guided by the following research question: What are the social determinants of health associated with the occurrence of $\mathrm{AH}$ in childhood? For its elaboration, the PICo strategy was adopted, in which the P corresponds to Participants, I to the phenomenon of Interest and Co to the Context of the study ${ }^{(12)}$. Subsequently, the controlled and uncontrolled index (CUI) were selected from the Health Sciences Descriptors (DeCS), Medical Subject Headings (MeSH) and List of Headings from CINAHL Information Systems, which are presented in Chart 1.

The search in the literature occurred between May and July 2017, simultaneously, by three researchers in databases accessed through the Portal of Journals of the Coordination of Improvement of Higher Education Personnel (CAPES), in an area with Internet Protocol (IP). The bases searched were: Index to Nursing and Allied Health Literature (Cinahl), Latin American and Caribbean Literature in Health Sciences (Lilacs), and Medline (International Literature in Health Sciences), via PubMed.
Chart 1 - Stratification of the research question following the PICo strategy ${ }^{(12)}$, Teresina, Piauí, Brazil, 2017

\begin{tabular}{|c|c|c|c|c|c|}
\hline Description & PICo & Components & Descriptor & Type & CUI \\
\hline Participants & $P$ & Child & $\begin{array}{c}\text { Child } \\
\text { ChildPreschool }\end{array}$ & $\begin{array}{l}\text { DeCS } \\
\text { MeSH } \\
\text { Titles } \\
\text { Cinahl }\end{array}$ & Childhood \\
\hline $\begin{array}{l}\text { Phenomenon } \\
\text { of Interest }\end{array}$ & 1 & $\begin{array}{c}\text { Social } \\
\text { Determinants } \\
\text { of Health }\end{array}$ & $\begin{array}{c}\text { Social Determinants of Health } \\
\text { Socioeconomic Factors } \\
\text { Cultural Characteristics } \\
\text { Ethnic Groups } \\
\text { Population Groups } \\
\text { Psychological Phenomena and Processes } \\
\text { Risk Factors } \\
\text { Dangerous Behavior }\end{array}$ & $\begin{array}{l}\text { DeCS } \\
\text { MeSH } \\
\text { Titles } \\
\text { Cinahl }\end{array}$ & $\begin{array}{c}\text { Reckless behavior } \\
\text { Life conditions } \\
\text { Breed } \\
\text { Genre }\end{array}$ \\
\hline $\begin{array}{l}\text { Context of } \\
\text { study }\end{array}$ & Co & $\begin{array}{l}\text { Accidents at } \\
\text { Home }\end{array}$ & Accidentes, Home & $\begin{array}{l}\text { DeCS } \\
\text { MeSH } \\
\text { Titles } \\
\text { Cinahl }\end{array}$ & $\begin{array}{l}\text { Accidentes, Home } \\
\text { Wounds and Injuries } \\
\text { Accident Prevention } \\
\text { Unintentional Injury }\end{array}$ \\
\hline
\end{tabular}

Nota: $P$ - participants; I-phenomenon of interest; $\mathrm{Co}$-Context of study; $\mathrm{MeSH}=$ controlled vocabulary of PubMed databe; $\mathrm{CUI}=\mathrm{Controlled}$ and uncontrolled index; Titles Cinahl = controlled vocabulary of Cinahl database; DeCS = controlled vocabulary of Lilacs database. 
As inclusion criteria, we adopted: primary studies that addressed the relation between the social determinants of health and the occurrence of $\mathrm{AH}$ in childhood; published in English, Portuguese or Spanish. Studies related to the other age range other than childhood, studies of traditional literature review or systematic or integrative review, studies that analyzed $\mathrm{AH}$ associated with other types of accidents (such as traffic accidents), those selected in the search for another database and studies that did not respond to the question of research. It is emphasized that the temporal cut-off for the selection of articles was not carried out, since a broad approach was sought.

The selection of the studies was initially performed by reading the titles and abstracts, based on the inclusion criteria, totaling 1,040 articles. 150 publications were considered potentially eligible and selected for reading in full, of which 31 were included in the final sample of this integrative review, as shown in Figure 1 , which followed the PRISMA guidelines ${ }^{(13)}$.

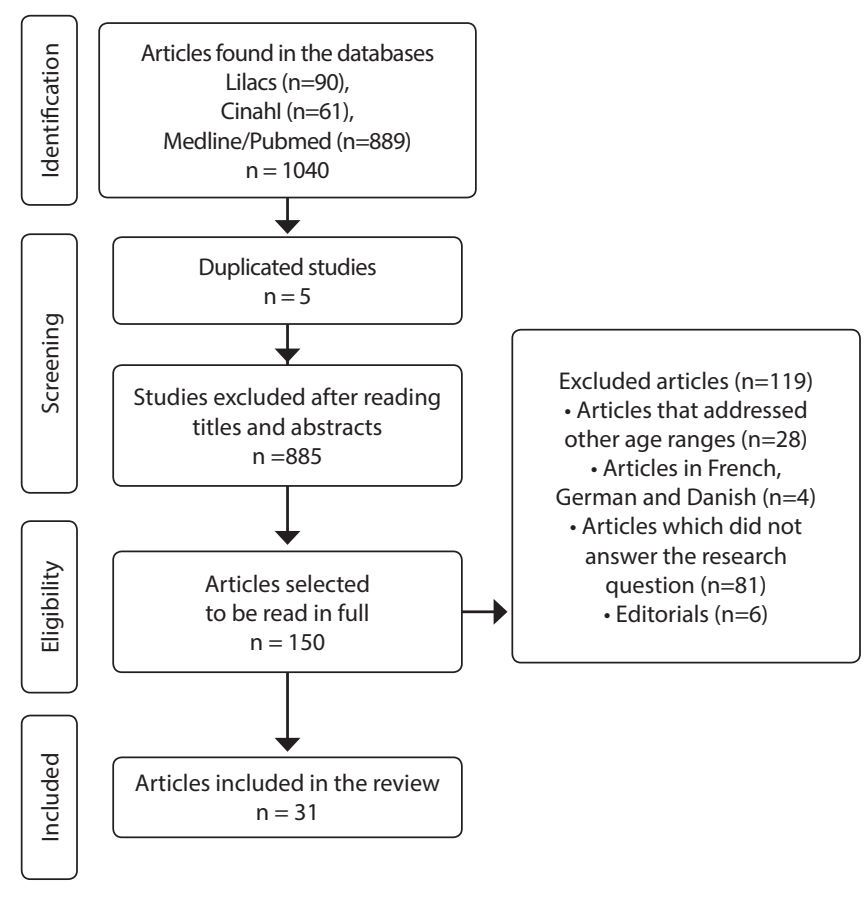

Figure 1 - Sample selection flowchart according to the Preferred Reporting Items for Systematic Reviews and Meta-Analyses (PRISMA)

A complete reading of the selected articles was conducted, and data extraction was done using an adapted data collection form ${ }^{(14)}$ capable of ensuring that all relevant data were extracted. The data included: definition of objects, methodology, sample size, variables measurement, method of analysis and concepts employed.

Regarding the underlying concepts, it should be pointed out that childhood was considered according to the proposal of the Statute of the Child and Adolescent (Federal Law 8.069/90) that considers a child to be a person under 12 incomplete years ${ }^{(15)}$; and that the definition of social determinants of health was established from the proposal of the National Commission on Social Determinants of Health, which specifies the social, economic, cultural, ethnic/racial, psychological and behavioral factors that influence the occurrence of health problems and their risk factors in the population, such as housing, food, education, income and employment ${ }^{(16)}$. Finally, $\mathrm{AH}$ was considered the unintentional and avoidable event, causing physical and emotional damage, occurring in the home environment (living/family living space), excluding social environments (traffic, school, sports and leisure outside the home) $)^{(17)}$

To evaluate extracted data, the Brazilian Center for EvidenceBased Health Care was determined by the Collaborating Center of the Joanna Briggs Institute (JBI), Brazil, based at the University of São Paulo (USP). The Levels of Evidence according to the type of study, according to the JBI are: Level I - Evidence obtained from a systematic review containing only randomized controlled clinical trials; Level II - Evidence obtained from at least one randomized controlled trial; Level III. 1 - Evidence obtained from well-outlined controlled clinical trials, without randomization; Level III. 2 - Evidence obtained from well-outlined or case-control and cohort studies, analytical studies, preferably from more than one research center or group; Level III. 3 - Evidence obtained from multiple time series, with or without intervention and dramatic results in uncontrolled experiments; Level IV - Opinion of respected experts in their fields, based on clinical criteria and experience, descriptive studies or reports of expert committees ${ }^{(12)}$.

The analysis of data of the articles included in the review involved a complete and impartial interpretation of primary sources, together with an innovative synthesis of evidence ${ }^{(11)}$. The data obtained through the analysis of the objectives, results and conclusion of each study were grouped by similarity and organized into thematic categories, which had as their guiding principle the model proposed by Dahlgren and Whitehead. In this model, the SDH are arranged in different layers, from a layer closer to the individual determinants to a distal layer, in which the macrodeterminants ${ }^{(16)}$ are located. Thus, the presentation, analysis and discussion of data were divided into theoretical categories, according to the SDH, into: Proximal Determinants, represented by the operational categories related to the individual, such as age, sex, hereditary and ethnic/racial factors; Intermediate Determinants, which comprise the operational categories of lifestyle and social and community networks; and Distal Determinants (education, work environment, source of income, basic sanitation, culture, housing and social and health services) and general socioeconomic, cultural and environmental conditions ${ }^{(9)}$.

\section{RESULTS}

The characterization of the studies included in the review is presented in Chart 2. The years of publication varied between 1983 and 2017, and most of them were published as of 2010 (19 articles). Considering the place of development of the studies, most ( 8 articles) were carried out in North American countries (six in the United States - USA, and two in Canada). Regarding the types of $\mathrm{AH}$ analyzed in the surveys, the majority involved "general AHs" (16 articles), classification attributed to studies that did not specify $\mathrm{AH}$ or that addressed three or more accidents in the analysis; followed by seven articles that analyzed SDH related to Poisoning/Intoxication. As to the design, all the studies presented a quantitative approach, predominating the level of evidence III. (20 articles) ${ }^{(12)}$. 
Chart 2 - Characterization of selected studies in chronological order according to authors, country, study design, number of participants, objectives, social determinants of health, main results and level of evidence, 2017

\begin{tabular}{|c|c|c|c|c|c|}
\hline Authors & $\begin{array}{c}\text { Country/ } \\
\text { Year }\end{array}$ & $\begin{array}{l}\text { Study outline/ } \\
\text { number of } \\
\text { participants }\end{array}$ & Objectives & $\begin{array}{l}\text { Social Determinants of Health/ } \\
\text { Main results }\end{array}$ & LV \\
\hline $\begin{array}{l}\text { Mahdi AH, } \\
\text { Taha AS, } \\
\text { Al Rifai MR }{ }^{(18)}\end{array}$ & $\begin{array}{c}\text { Saudi } \\
\text { Arabia } \\
1983\end{array}$ & $\begin{array}{l}\text { Prospective } \\
\text { longitudinal } \\
\text { study/ } \mathrm{N}=178\end{array}$ & $\begin{array}{l}\text { To outline the } \\
\text { etiological and } \\
\text { ecological factors } \\
\text { responsible for } \\
\text { accidents in Riyadh } \\
\text { (Saudi Arabia) and } \\
\text { suggest relevant } \\
\text { preventive actions for } \\
\text { this society. }\end{array}$ & $\begin{array}{l}\text { Proximal DSH: (child's age; child's sex). Intermediate DSH: } \\
\text { (behavioral factors - supervision). Distal DSH: (housing; } \\
\text { employment situation of father/mother; social factors; economic } \\
\text { factors; cultural factors; education of parents). } \\
\text { The AH addressed were Poisoning/Intoxication. The age range of } \\
\text { children was from six months to seven years old, predominantly } \\
\text { male. Most mothers were unaware of the toxicity potential of the } \\
\text { substances. In } 18 \% \text { of cases supervision was delegated to an older } \\
\text { child (sibling); } 38 \% \text { of families lived in small apartments and } 30 \% \\
\text { in isolated houses in poor neighborhoods. In } 80 \% \text { of cases the } \\
\text { father of the child had primary education and the mother had no } \\
\text { formal education. }\end{array}$ & III 3 \\
\hline Mott JA ${ }^{(19)}$ & $\begin{array}{l}\text { USA } \\
1999\end{array}$ & $\begin{array}{l}\text { Retrospective } \\
\text { longitudinal } \\
\text { study/ } \mathrm{N}=2.036\end{array}$ & $\begin{array}{l}\text { To examine the } \\
\text { independent } \\
\text { contributions of } \\
\text { demographic, behavioral } \\
\text { and environmental } \\
\text { antecedents of medically } \\
\text { assisted pediatric } \\
\text { domestic injuries. }\end{array}$ & $\begin{array}{l}\text { Proximal DSH: (child's sex; ethnicity/race). Distal DSH: (living } \\
\text { conditions, housing, mother's education, social factors, } \\
\text { economic factors, access to health services). } \\
\text { General AHs were addressed. Boys were more likely to suffer a } \\
\text { home injury. White, non-Hispanic children were significantly } \\
\text { more likely too. Uninsured children were more likely to live } \\
\text { below the poverty level and in households characterized as } \\
\text { disordered, factors associated with the occurrence of injuries. }\end{array}$ & III 3 \\
\hline $\begin{array}{l}\text { Ramsay } \mathrm{L}, \\
\text { Moreton G, } \\
\text { Gorman DR, } \\
\text { Blake } \mathrm{E}, \mathrm{Goh} \mathrm{D}, \\
\text { Elton RA et al }{ }^{(20)}\end{array}$ & $\begin{array}{l}\text { United } \\
\text { Kingdom } \\
2003\end{array}$ & $\begin{array}{l}\text { Case-control } \\
\text { prospective } \\
\text { study/ } \mathrm{N}=207\end{array}$ & $\begin{array}{l}\text { To investigate the } \\
\text { physical, social } \\
\text { and psychological } \\
\text { environment of families } \\
\text { with preschool children } \\
\text { to identify the most } \\
\text { significant risk factors } \\
\text { for unintentional } \\
\text { injuries. }\end{array}$ & $\begin{array}{l}\text { Proximal DSH: (child's sex). Intermediate DSH: (mother's age). } \\
\text { Distal DSH: (living conditions, employment of the father/mother). } \\
\text { General AHs were addressed. For the case group, the child's } \\
\text { primary caregiver was single, the majority received some benefit } \\
\text { from the government. The assessment of physical and mental } \\
\text { well-being did not reveal differences in both groups. A larger } \\
\text { proportion (19\%) of the group of cases did not receive social } \\
\text { support when compared to those controlled, who received more } \\
\text { support from friends and neighbors. The families of cases had } \\
\text { more children. }\end{array}$ & III 2 \\
\hline $\begin{array}{l}\text { Ramos CLJ, } \\
\text { Targa MBM, } \\
\text { Stein } A T^{(21)}\end{array}$ & $\begin{array}{l}\text { Brazil } \\
2005\end{array}$ & $\begin{array}{l}\text { Transversal } \\
\text { study with } \\
\text { descriptive } \\
\text { and analytical } \\
\text { components/ } \\
\mathrm{N}=286\end{array}$ & $\begin{array}{l}\text { To identify the profile } \\
\text { of intoxications and } \\
\text { risk factors in children } \\
\text { under four, in Porto } \\
\text { Alegre City. }\end{array}$ & $\begin{array}{l}\text { Proximal DSH: (child's age; child's sex). Distal DSH: (housing; } \\
\text { access to health services). } \\
\text { The AH addressed were Poisoning/Intoxication. The most } \\
\text { common age of accident occurrence was one ( } 28.5 \%) .53 .3 \% \\
\text { were boys. }\end{array}$ & III 3 \\
\hline $\begin{array}{c}\text { Lima RP, } \\
\text { Ximenes LB, } \\
\text { Vieira LJES, } \\
\text { Oriá MOB(22) }\end{array}$ & $\begin{array}{l}\text { Brazil } \\
2006\end{array}$ & $\begin{array}{c}\text { Descriptive } \\
\text { study with } \\
\text { quantitative } \\
\text { approach/ } \mathrm{N}=65\end{array}$ & $\begin{array}{l}\text { To trace the } \\
\text { sociodemographic } \\
\text { profile of families } \\
\text { whose children in early } \\
\text { childhood experienced } \\
\text { domestic accidents. }\end{array}$ & $\begin{array}{l}\text { Proximal DSH: (child's sex). Intermediate DSH: (mother's age). } \\
\text { Distal DSH: (living conditions, housing, mother's education, } \\
\text { social factors, economic factors, access to health services). } \\
\text { General AH were addressed. There was a higher frequency } \\
\text { of boys and unfavorable socio-demographic conditions. The } \\
\text { sanitary conditions were precarious, the houses had few rooms, } \\
\text { which favored the crowding of people in small spaces. There } \\
\text { was no statistically significant association between mother's } \\
\text { occupation, income and the occurrence of AH. }\end{array}$ & III 3 \\
\hline $\begin{array}{l}\text { Moreira BFC, } \\
\text { Vieira LJES, } \\
\text { Oriá MOB, } \\
\text { Ximenes LB, } \\
\text { Almeida PC(23) }\end{array}$ & $\begin{array}{l}\text { Brazil } \\
2008\end{array}$ & $\begin{array}{c}\text { Descriptive } \\
\text { study with } \\
\text { quantitative } \\
\text { approach/ } \mathrm{N}=87\end{array}$ & $\begin{array}{l}\text { To identify the presence } \\
\text { of risk factors for the } \\
\text { occurrence burns and } \\
\text { electric shock, in the } \\
\text { opinion of the mothers } \\
\text { and the researcher, in } \\
\text { children during early } \\
\text { childhood, and to verify } \\
\text { the association with the } \\
\text { sociodemographic data } \\
\text { of mothers. }\end{array}$ & $\begin{array}{l}\text { Intermediate DSH: (behavioral factors). Distal DSH: (life } \\
\text { conditions; housing; mother's education). } \\
\text { The AHs addressed were Burns and Electric Shock. In } \\
\text { general, mothers were between } 21 \text { and } 40 \text {, with a family } \\
\text { income between one and two minimum wages, whose main } \\
\text { occupation was to be housewives. It was verified that the } \\
\text { researcher had a higher percentage of identification of risk } \\
\text { factors than mothers, since they identified } 98.85 \% \text { of risk } \\
\text { factors, whereas mothers, } 66.70 \% \text {. The identification of risk } \\
\text { factors was not influenced by income ( } p=0.943) \text {, age ( } p=0.973) \text {, } \\
\text { occupation ( } p=0.887 \text { ) and marital status }(p=0.899) \text {. }\end{array}$ & III 3 \\
\hline
\end{tabular}




\begin{tabular}{|c|c|c|c|c|c|}
\hline Authors & $\begin{array}{c}\text { Country/ } \\
\text { Year }\end{array}$ & $\begin{array}{c}\text { Study outline/ } \\
\text { number of } \\
\text { participants }\end{array}$ & Objectives & $\begin{array}{l}\text { Social Determinants of Health/ } \\
\text { Main results }\end{array}$ & LV \\
\hline $\begin{array}{c}\text { Liyanage IK, } \\
\text { Pathirana AC, } \\
\text { Wickramasinghe KK, } \\
\text { Karunathilake IM, } \\
\text { Olupaliyawa } \mathrm{A}^{(24)}\end{array}$ & $\begin{array}{l}\text { Sri Lanka } \\
2008\end{array}$ & $\begin{array}{l}\text { Transversal } \\
\text { study with } \\
\text { descriptive } \\
\text { and analytical } \\
\text { components/ } \\
\quad \mathrm{N}=270\end{array}$ & $\begin{array}{l}\text { To identify risk factors } \\
\text { for unintentional } \\
\text { injuries at home among } \\
\text { pre-schoolers in three } \\
\text { suburban areas of Sri } \\
\text { Lanka. }\end{array}$ & $\begin{array}{l}\text { Distal DSH: (education of parents; access to health services). } \\
\text { The study addressed general AH. Parental identification of risk } \\
\text { factors was lower. The educational level of parents significantly } \\
\text { affected the prevalence of risk factors ( } P<0.05) \text {. Only } 38 \% \\
\text { received education on injury prevention, and the doctor in } \\
\text { charge advised only } 5 \% \text { of the parents. }\end{array}$ & III 3 \\
\hline $\begin{array}{l}\text { Morrongiello BA, } \\
\text { Klemencic N, } \\
\text { Corbett } \mathrm{M}^{(25)}\end{array}$ & $\begin{array}{l}\text { Canada } \\
2008\end{array}$ & $\begin{array}{l}\text { Transversal } \\
\text { study with } \\
\text { descriptive } \\
\text { and analytical } \\
\text { components/ } \\
\quad \mathrm{N}=124\end{array}$ & $\begin{array}{l}\text { To evaluate the } \\
\text { interactions between } \\
\text { risk factors "behavioral } \\
\text { attributes of the } \\
\text { child" and "patterns of } \\
\text { parental supervision". }\end{array}$ & $\begin{array}{l}\text { Proximal DSH: (child's age; child's sex; ethnicity/race). } \\
\text { Intermediate DSH: (behavioral factors). Distal DSH: (mother's } \\
\text { education; economic factors). } \\
\text { General AH were addressed. A higher score for boys was } \\
\text { identified in the features' indicative of more energetic and } \\
\text { intense behavior, while the mean scores for girls were higher in } \\
\text { the attribute indicative of self-control. Children with a higher } \\
\text { self-control score were not frequently supervised by mothers. } \\
\text { In contrast, children with a high activity level were supervised } \\
\text { more frequently. }\end{array}$ & III 3 \\
\hline $\begin{array}{c}\text { Schmertmann M, } \\
\text { Williamson A, } \\
\text { Black D }{ }^{(26)}\end{array}$ & $\begin{array}{l}\text { Australia } \\
2008\end{array}$ & $\begin{array}{c}\text { Retrospective } \\
\text { longitudinal } \\
\text { study/ } \mathrm{N}=8.472\end{array}$ & $\begin{array}{l}\text { Investigate whether } \\
\text { child development } \\
\text { plays any role } \\
\text { in unintentional } \\
\text { poisoning. }\end{array}$ & $\begin{array}{l}\text { Proximal DSH: (child's age; child's sex; ethnicity/race). } \\
\text { Intermediate DSH: (behavioral factors). Distal DSH: (mother's } \\
\text { education; economic factors). } \\
\text { The AH addressed were Poisoning/Intoxication. Boys and } \\
\text { girls had the same age pattern for hospitalization rates for } \\
\text { poisoning. Rates of hospitalization for unintended intoxication } \\
\text { were significantly higher in children aged one to three than } \\
\text { among children under one and four. }\end{array}$ & III 3 \\
\hline $\begin{array}{l}\text { Belonwu RO, } \\
\text { Adeleke } \mathrm{SI}^{(27)}\end{array}$ & $\begin{array}{l}\text { Nigeria } \\
2008\end{array}$ & $\begin{array}{c}\text { Descriptive } \\
\text { study with } \\
\text { quantitative } \\
\text { approach/ N= } \\
55\end{array}$ & $\begin{array}{l}\text { To determine the } \\
\text { magnitude of accidental } \\
\text { kerosene intake in } \\
\text { children's morbidity/ } \\
\text { mortality and to provide } \\
\text { viable solutions to } \\
\text { reduce the frequency of } \\
\text { occurrence. }\end{array}$ & $\begin{array}{l}\text { Proximal DSH: (child's age; child's sex). } \\
\text { The AH addressed were Poisoning/Intoxication. The study } \\
\text { showed that children aged four months to eight years old were } \\
\text { affected at the peak age of } 18 \text { months. In } 61.8 \% \text { of the cases } \\
\text { they were less than two years old. }\end{array}$ & III 3 \\
\hline $\begin{array}{c}\text { Simpson JC, } \\
\text { Turnbull BL, } \\
\text { Ardagh } \mathrm{M}, \\
\text { Richardson } \mathrm{S}^{(28)}\end{array}$ & $\begin{array}{l}\text { New } \\
\text { Zealand } \\
2009\end{array}$ & $\begin{array}{c}\text { Descriptive } \\
\text { study with } \\
\text { quantitative } \\
\text { approach/ } \mathrm{N}= \\
100\end{array}$ & $\begin{array}{l}\text { To investigate the } \\
\text { circumstances of } \\
\text { injuries at home among } \\
\text { children from } 0 \text { to } 4 \\
\text { years old. }\end{array}$ & $\begin{array}{l}\text { Proximal DSH: (child's age; child's sex). Intermediate DSH: } \\
\text { (behavioral factors). Distal DSH: (living conditions, housing, } \\
\text { economic factors, cultural factors). } \\
\text { General AH were addressed. The caregivers of the children at } \\
\text { the time of the accident were mostly women between the ages } \\
\text { of } 25 \text { and 34, and the age group with the highest incidence of } \\
\text { accidents was between two and three. }\end{array}$ & III 3 \\
\hline $\begin{array}{c}\text { Morrongiello BA, } \\
\text { Corbett M, } \\
\text { Brison } \mathrm{RJ}^{(29)}\end{array}$ & $\begin{array}{l}\text { Canada } \\
2009\end{array}$ & $\begin{array}{l}\text { Quasi- } \\
\text { experimental } \\
\text { case-control } \\
\text { study/ } \mathrm{N}=70\end{array}$ & $\begin{array}{l}\text { To investigate the } \\
\text { difference between } \\
\text { small children injured } \\
\text { and those not injured, } \\
\text { based on the child's } \\
\text { behavioral attributes } \\
\text { and caregiver } \\
\text { supervision indexes. }\end{array}$ & $\begin{array}{l}\text { Proximal DSH: (child's sex). } \\
\text { Intermediate DSH: (behavioral factors; mother's supervision). } \\
\text { Distal DSH: (housing). } \\
\text { General AH were addressed. The results revealed that there } \\
\text { are no differences between groups of children regarding } \\
\text { behavioral attributes. However, the control group received } \\
\text { more supervision in general and during specific activities } \\
\text { leading to injuries. }\end{array}$ & III 2 \\
\hline $\begin{array}{c}\text { Ramos CL, } \\
\text { Barros HM, Stein AT, } \\
\text { Costa } J^{(30)}\end{array}$ & $\begin{array}{l}\text { Brazil } \\
2010\end{array}$ & $\begin{array}{c}\text { Case-control } \\
\text { study/ } \\
\mathrm{N}(\text { caso })=25 \\
\mathrm{~N}(\text { controle })=25\end{array}$ & $\begin{array}{l}\text { To investigate whether } \\
\text { the lack of knowledge } \\
\text { about toxic agents at } \\
\text { home is a risk factor for } \\
\text { unintentional poisoning } \\
\text { in childhood. }\end{array}$ & $\begin{array}{l}\text { Proximal DSH: (child's age; child's sex). } \\
\text { Intermediate DSH: (behavioral factors). Distal DSH: (housing, } \\
\text { mother's employment, economic factors). } \\
\text { The AH addressed were Poisoning/Intoxication. The mean } \\
\text { age of the children was } 31.8 \text { months. The distraction was } 15 \\
\text { times more likely to occur among caregivers of children who } \\
\text { underwent poisoning compared to the control group. Among } \\
\text { the families interviewed, } 64 \% \text { in the case group and } 60 \% \text { in the } \\
\text { control group belonged to the lower socioeconomic classes. }\end{array}$ & III 2 \\
\hline
\end{tabular}




\begin{tabular}{|c|c|c|c|c|c|}
\hline Authors & $\begin{array}{l}\text { Country/ } \\
\text { Year }\end{array}$ & $\begin{array}{l}\text { Study outline/ } \\
\text { number of } \\
\text { participants }\end{array}$ & Objectives & $\begin{array}{l}\text { Social Determinants of Health/ } \\
\text { Main results }\end{array}$ & LV \\
\hline $\begin{array}{c}\text { Atak N, } \\
\text { Karaoğlu L, } \\
\text { Korkmaz Y, } \\
\text { Usubütün } \mathrm{S}^{(31)}\end{array}$ & $\begin{array}{c}\text { Tunisia } \\
2010\end{array}$ & $\begin{array}{c}\text { Transversal } \\
\text { epidemiological } \\
\text { study/ } \mathrm{N}=704\end{array}$ & $\begin{array}{l}\text { To investigate } \\
\text { the frequency of the } \\
\text { accident that causes the } \\
\text { injury } \\
\text { among children less than } \\
\text { five who live } \\
\text { in the province of Malatya } \\
\text { and the related factors, } \\
\text { including the mother's } \\
\text { level of knowledge } \\
\text { on possible accident risks } \\
\text { at home. }\end{array}$ & $\begin{array}{l}\text { Proximal DSH: (child's age; child's sex). Intermediate DSH: } \\
\text { (mother's age; mother's supervision; behavioral factors). Distal } \\
\text { DSH: (employment of mother and father; mother's education). } \\
\text { General AH were addressed. Most accidents took place at } \\
\text { home, and } 65.3 \% \text { of them were due to falls; } 65.1 \% \text { took place } \\
\text { in the presence of the mother. The frequency of accidents was } \\
\text { higher in the age range from } 4 \text { to } 5 \text { years old and lower in the } \\
\leq 1 \text { year group. }\end{array}$ & III 3 \\
\hline $\begin{array}{c}\text { Manzar N, } \\
\text { Saad SM, } \\
\text { Manzar B, } \\
\text { Fatima SS }\end{array}$ & $\begin{array}{l}\text { Pakistan } \\
2010\end{array}$ & $\begin{array}{l}\text { Case series, } \\
\text { retrospective } \\
\text { and non- } \\
\text { interventionist } \\
\text { study/ } \mathrm{N}=100\end{array}$ & $\begin{array}{l}\text { To determine the } \\
\text { poisoning agents and } \\
\text { demographic distribution } \\
\text { of children brought } \\
\text { to the Karachi Civil } \\
\text { Hospital with a history of } \\
\text { accidental poisoning and } \\
\text { to examine the factors } \\
\text { associated with it. }\end{array}$ & $\begin{array}{l}\text { Proximal DSH: (child's age; child's sex). Intermediate DSH: } \\
\text { (behavioral factors; lifestyle). Distal DSH: (mother's education; } \\
\text { housing; economic factors). } \\
\text { The AH addressed were Poisoning/Intoxication. Factors such as } \\
\text { mother's education, number of siblings and place of storage of } \\
\text { substances were significantly related with cases of accidental } \\
\text { poisoning. The mortality rate was } 3 \% \text {. }\end{array}$ & III 3 \\
\hline $\begin{array}{c}\text { Shields BJ, } \\
\text { Pollack-Nelson C, } \\
\text { Smith } \mathrm{GA}^{(33)}\end{array}$ & $\begin{array}{l}\text { USA } \\
2011\end{array}$ & $\begin{array}{l}\text { Retrospective } \\
\text { longitudinal } \\
\text { study/ } \mathrm{N}=244\end{array}$ & $\begin{array}{l}\text { To describe the } \\
\text { epidemiology of } \\
\text { drowning events that } \\
\text { occur with kids in } \\
\text { portable swimming } \\
\text { pools in the United } \\
\text { States. }\end{array}$ & $\begin{array}{l}\text { Proximal DSH: (child's age; child's sex). Intermediate DSH: } \\
\text { (behavioral factors; supervision). Distal DSH: (housing; rooms in } \\
\text { general). } \\
\text { AH were approached by Drowning. A total of } 209 \text { cases of fatal } \\
\text { and } 35 \text { non-fatal drownings were identified between } 2001 \text { and } \\
2009 \text {. The majority }(94 \%) \text { involved children under five, } 56 \% \text { were } \\
\text { boys. } 73 \% \text { occurred in the child's home. }\end{array}$ & III 3 \\
\hline $\begin{array}{c}\text { Carlsson A, } \\
\text { Bramhagen AC, } \\
\text { Jansson A, } \\
\text { Dykes AK }{ }^{(34)}\end{array}$ & $\begin{array}{l}\text { Sweden } \\
2011\end{array}$ & $\begin{array}{l}\text { Quasi- } \\
\text { experimental } \\
\text { case-control } \\
\text { study/ } \\
\mathrm{N}(\text { cases })=50 \\
\mathrm{~N}(\text { control) }=50\end{array}$ & $\begin{array}{l}\text { To investigate how } \\
\text { information provided } \\
\text { to mothers of low } \\
\text { education can improve } \\
\text { the precautions taken } \\
\text { to prevent burn injuries } \\
\text { involving young } \\
\text { children; and to compare } \\
\text { the results with a group } \\
\text { of mothers who did not } \\
\text { receive information. }\end{array}$ & $\begin{array}{l}\text { Distal DSH: (mother's education). } \\
\text { AH by Burns/Scalding were addressed. The results showed that } \\
\text { the intervention had a significant impact on improving the } \\
\text { precautions mothers have taken to protect their children from } \\
\text { burns and bruises at home. }\end{array}$ & III 2 \\
\hline \begin{tabular}{|c|} 
Johnston $B D$, \\
Quistberg $D A$, \\
Shandro JR, \\
Partridge RL, \\
Song HR, Ebel BE \\
\end{tabular} & $\begin{array}{l}\text { USA } \\
2011\end{array}$ & $\begin{array}{l}\text { Quasi- } \\
\text { experimental } \\
\text { case-control } \\
\text { study/ } \\
\mathrm{N}(\text { cases })=18 \\
\mathrm{~N}(\text { control) }=14\end{array}$ & $\begin{array}{l}\text { To estimate the } \\
\text { prevalence of potential } \\
\text { risk factors for falling } \\
\text { from } \\
\text { windows. }\end{array}$ & $\begin{array}{l}\text { Proximal DSH: (child's age; child's sex). Distal DSH: (housing; } \\
\text { economic factors). } \\
\text { AH by Falls from Windows were addressed. The falls mostly } \\
\text { happened in the rooms of the child's house. Most were boys. } \\
\text { The main risk factors were the type of window, external height, } \\
\text { depth of the threshold and absence of screen protection. }\end{array}$ & III 2 \\
\hline $\begin{array}{l}\text { Pearce A, Li L, } \\
\text { Abbas J, } \\
\text { Ferguson B, } \\
\text { Graham H, } \\
\text { Law } C^{(36)}\end{array}$ & $\begin{array}{l}\text { United } \\
\text { Kingdom } \\
2012\end{array}$ & $\begin{array}{l}\text { Cohort study/ } \\
\mathrm{N}=14.378\end{array}$ & $\begin{array}{l}\text { To explore the } \\
\text { home environment } \\
\text { as a potential } \\
\text { mediator between } \\
\text { socioeconomic } \\
\text { circumstances and } \\
\text { unintentional injuries. }\end{array}$ & $\begin{array}{l}\text { Intermediate DSH: (mother's age; behavioral factors; social } \\
\text { and community networks). Distal DSH: (housing; social factors; } \\
\text { economic factors). } \\
\text { General AH were addressed. Most children lived in households } \\
\text { with poor housing scores and were more likely to suffer injuries } \\
\text { at home. }\end{array}$ & III 2 \\
\hline $\begin{array}{l}\text { Güloğlu R, } \\
\text { Sarıcı IS, } \\
\text { Bademler S, } \\
\text { Emirikçi S, } \\
\text { Işsever H, } \\
\text { Yanar H et al. }{ }^{(37)}\end{array}$ & $\begin{array}{c}\text { Turkey } \\
2012\end{array}$ & $\begin{array}{l}\text { Retrospective } \\
\text { longitudinal } \\
\text { study/ } \mathrm{N}=42\end{array}$ & $\begin{array}{l}\text { To review the TV-related } \\
\text { injuries to determine } \\
\text { the risk factors, type of } \\
\text { injuries, and operative } \\
\text { intervention(s) needed } \\
\text { in children injured by } \\
\text { TV accidents. }\end{array}$ & $\begin{array}{l}\text { Proximal DSH: (child's age; child's sex). Intermediate DSH: } \\
\text { (mother/father supervision). Distal DSH: (housing). } \\
\text { AH by TV devices were addressed. More than } 65 \% \text { of the } \\
\text { children were between one and three. The injuries rate was } \\
\text { higher in boys ( } 66.7 \% \text { ) than in girls ( } 33.3 \%) \text {. The most common } \\
\text { mechanism of injuries ( } 71.4 \% \text { ) among all age groups was } \\
\text { device fall. Pulling the TV to one's direction (19\%) was the } \\
\text { second most frequent mechanism of injuries. }\end{array}$ & III 3 \\
\hline
\end{tabular}




\begin{tabular}{|c|c|c|c|c|c|}
\hline Authors & $\begin{array}{c}\text { Country/ } \\
\text { Year }\end{array}$ & $\begin{array}{c}\text { Study outline/ } \\
\text { number of } \\
\text { participants }\end{array}$ & Objectives & $\begin{array}{l}\text { Social Determinants of Health/ } \\
\text { Main results }\end{array}$ & LV \\
\hline $\begin{array}{c}\text { Carlberg MM, } \\
\text { Shapiro-Mendoza } \\
\text { CK, Goodman M(38) }\end{array}$ & $\begin{array}{l}\text { USA } \\
2012\end{array}$ & $\begin{array}{l}\text { Cohort study/ } \\
\qquad \mathrm{N}=1.064\end{array}$ & $\begin{array}{l}\text { To identify maternal and } \\
\text { infant characteristics } \\
\text { associated with } \\
\text { accidental suffocation } \\
\text { and bed strangulation } \\
\text { (ASBS) in American } \\
\text { infants. }\end{array}$ & $\begin{array}{l}\text { Proximal SDH: (child's age; child's sex; ethnicity/race). Intermediate } \\
\text { SDH: (mother's age; lifestyle). Distal SDH: (access to health services; } \\
\text { mother's education). } \\
\text { The AH addressed were Accidental Suffocation and Strangulation. } \\
\text { The children with the highest ASBS mortality rates were boys and } \\
\text { were born between } 20 \text { and } 33 \text { weeks of pregnancy. The majority } \\
\text { of ASBS mortality ( } 71 \% \text { ) occurred before the infant reached four } \\
\text { months. The mothers of babies with the highest ASBS mortality } \\
\text { rates were black, non-Hispanic, Native American/Alaska Native, } \\
\text { smoked during pregnancy, were younger, had less than } 12 \text { years } \\
\text { of education, and had not undergone prenatal care. }\end{array}$ & III 2 \\
\hline $\begin{array}{c}\text { Vieira LJEDS, } \\
\text { Pordeus AMJ, } \\
\text { Lira SVG, } \\
\text { Moreira DP, } \\
\text { Pereira ADS, } \\
\text { Barbosa IL }{ }^{(39)}\end{array}$ & $\begin{array}{l}\text { Brazil } \\
2012\end{array}$ & $\begin{array}{c}\text { Transversal } \\
\text { study/ N=362 }\end{array}$ & $\begin{array}{l}\text { To portray the } \\
\text { sociodemographic } \\
\text { profile of families } \\
\text { living in a low } \\
\text { income community; } \\
\text { and to identify the } \\
\text { associated factors } \\
\text { for the occurrence of } \\
\text { unintentional injuries in } \\
\text { children. }\end{array}$ & $\begin{array}{l}\text { Intermediate SDH: (parents' age; lifestyle; behavioral factors; social } \\
\text { and community networks). Distal SDH: (life conditions; housing; } \\
\text { basic sanitation; social factors; economic factors). } \\
\text { The study addressed general AH. According to the family type, the } \\
\text { majority ( } 62.7 \% \text { ) were nuclear (father, mother and children). As } \\
\text { for demographic density by residence, } 43.6 \% \text { of households had } \\
\text { four people and } 42.0 \% \text { of families had five to seven. Considering } \\
\text { the family income, } 71.0 \% \text { survived with up to a minimum wage. } \\
\text { In } 79.3 \% \text { of households, at least one person was employed. } \\
\text { In relation to the caregiver, the mother was cited in } 71.8 \% \text { of } \\
\text { the families. In } 50.1 \% \text { it has been reported that parents have } \\
\text { delegated responsibilities to their children. }\end{array}$ & III 3 \\
\hline $\begin{array}{l}\text { Shah M, Orton E, } \\
\text { Tata LJ, Gomes C, } \\
\text { Kendrick D }{ }^{(40)}\end{array}$ & $\begin{array}{l}\text { United } \\
\text { Kingdom } \\
2013\end{array}$ & $\begin{array}{c}\text { Case-control } \\
\text { study/ } \\
\mathrm{N}(\text { cases })=986 \\
\mathrm{~N}(\text { control })= \\
9240\end{array}$ & $\begin{array}{l}\text { To identify risk factors } \\
\text { for scald injuries in } \\
\text { children under } 5 \text {. }\end{array}$ & $\begin{array}{l}\text { Proximal SDH: (child's age; child's sex). Intermediate SDH: (mother's } \\
\text { age; order of birth; lifestyle - monoparental vs. biparental homes). } \\
\text { Distal SDH: (life conditions; social factors; economic factors). } \\
\text { The AH addressed were Burns/Scaldings. Multivariate analysis } \\
\text { showed that boys were 34\% more likely to suffer scald injuries. With } \\
\text { regard to age, children aged 1-2 were at higher risk when compared } \\
\text { to those younger than } 1 \text { year old. A high number of older siblings } \\
\text { were also associated with a greater chance of scalding injuries. } \\
\text { High maternal age at delivery was associated with a decrease in the } \\
\text { chance of scald injuries. Children living in households with single } \\
\text { adults showed an increased chance of injuries. }\end{array}$ & III 2 \\
\hline $\begin{array}{c}\text { Sheikh S, } \\
\text { Chang A, } \\
\text { Kieszak S, } \\
\text { Law R, } \\
\text { Bennett HKW, } \\
\text { Ernst E et al }{ }^{(41)}\end{array}$ & $\begin{array}{l}\text { USA } \\
2013\end{array}$ & $\begin{array}{l}\text { Transversal } \\
\text { study with } \\
\text { descriptive } \\
\text { and analytical } \\
\text { components/ } \\
\mathrm{N}=23.536\end{array}$ & $\begin{array}{l}\text { To characterize } \\
\text { demographic, health, } \\
\text { and potential risk factors } \\
\text { associated with lamp oil } \\
\text { poisoning reported by } \\
\text { poison center attendants } \\
\text { in the US, and discuss } \\
\text { their implications for } \\
\text { public health. }\end{array}$ & $\begin{array}{l}\text { Intermediate SDH: (behavioral factors). Distal SDH: (cultural factors). } \\
\text { The AH addressed were Poisoning/Intoxication. Most intakes } \\
\text { occurred in children who were two years old; they involved tiki } \\
\text { torch fuel products located on a table or shelf, and occurred indoors. } \\
\text { The amount of oil in the lamp ingested does not appear to be } \\
\text { associated with its odor ( } p=0.19 \text { ) or oil color ( } p=1.00) \text {. Most of the } \\
\text { exhibits were managed on-site and resulted in "effectless" medical } \\
\text { results. }\end{array}$ & III 3 \\
\hline Kamal NN ${ }^{(42)}$ & $\begin{array}{l}\text { Egypt } \\
2013\end{array}$ & $\begin{array}{l}\text { Transversal } \\
\text { study with } \\
\text { descriptive } \\
\text { and analytical } \\
\text { components/ } \\
\mathrm{N}=1255\end{array}$ & $\begin{array}{l}\text { To determine the } \\
\text { frequency, characteristics } \\
\text { and outcome of non- } \\
\text { intentional domestic } \\
\text { (non-fatal) injuries } \\
\text { among children under } \\
\text { five in rural El Minia } \\
\text { province for one year; } \\
\text { and to describe the } \\
\text { demographic risk factors } \\
\text { by a community-based } \\
\text { study. }\end{array}$ & $\begin{array}{l}\text { Proximal SDH: (child's age; child's sex). Intermediate SDH: } \\
\text { (lifestyle - monoparental vs. biparental homes). Distal SDH: } \\
\text { (parents' education; social factors; economic factors). } \\
\text { The study addressed general AH. Boys have slightly higher } \\
\text { injuries rates than girls. It was also determined that } 32.9 \% \text { of } \\
\text { children who suffered injuries at home had between } 24-35 \\
\text { months. The low educational level of parents significantly } \\
\text { increased the risk of injuries. It was significantly higher for the } \\
\text { children of families with lower income (p<0.05). Daughters } \\
\text { of young mothers with parents of lower education and low } \\
\text { socioeconomic status have a considerably higher risk of injuries. }\end{array}$ & III 3 \\
\hline $\begin{array}{c}\text { Qiu X, } \\
\text { Wacharasin C, } \\
\text { Deoisres W, } \\
\text { Yu J, Zheng Q }{ }^{(43)}\end{array}$ & $\begin{array}{l}\text { China } \\
2014\end{array}$ & $\begin{array}{c}\text { Transversal } \\
\text { study/ N=366 }\end{array}$ & $\begin{array}{l}\text { Relate the } \\
\text { characteristics of the } \\
\text { houses and family } \\
\text { relationships with the } \\
\text { risk factors for accidents } \\
\text { at home among } \\
\text { children aged from } 24 \\
\text { to } 47 \text { months. }\end{array}$ & $\begin{array}{l}\text { Proximal SDH: (child's age; ethnicity/race). Intermediate SDH: } \\
\text { (behavioral factors; psychological factors). Distal SDH: (social } \\
\text { factors; economic factors; cultural factors; housing). } \\
\text { AH were addressed in a general way. The results showed that a } \\
\text { greater number of household risks were significantly attributed } \\
\text { to school-age children. Migrant children are more exposed to } \\
\text { risks at home compared to local children. High family stress has } \\
\text { been identified as a risk factor as it can lead to mental distraction } \\
\text { of parents and disturb the child's emotional behavior. }\end{array}$ & III 3 \\
\hline
\end{tabular}




\begin{tabular}{|c|c|c|c|c|c|}
\hline Authors & $\begin{array}{c}\text { Country/ } \\
\text { Year }\end{array}$ & $\begin{array}{c}\text { Study outline/ } \\
\text { number of } \\
\text { participants }\end{array}$ & Objectives & $\begin{array}{l}\text { Social Determinants of Health/ } \\
\text { Main results }\end{array}$ & LV \\
\hline $\begin{array}{c}\text { Mayes S, } \\
\text { Roberts MC, } \\
\text { Stough } \mathrm{CO}^{(44)}\end{array}$ & $\begin{array}{l}\text { USA } \\
2014\end{array}$ & $\begin{array}{l}\text { Transversal } \\
\text { study/ } \mathrm{N}=80\end{array}$ & $\begin{array}{l}\text { To examine the } \\
\text { relation between the } \\
\text { socioeconomic and } \\
\text { sociodemographic } \\
\text { factors of the family and } \\
\text { the risk factors for the } \\
\text { domestic injury. }\end{array}$ & $\begin{array}{l}\text { Intermediate SDH: (parents' age). Distal SDH: (life conditions; } \\
\text { economic factors). } \\
\text { AH were addressed in a general way. In both low-income and } \\
\text { higher-income families, risk factors were found. However, } \\
\text { poorer families with younger parents have less knowledge to } \\
\text { identify risk factors for the occurrence of AH. }\end{array}$ & III 3 \\
\hline $\begin{array}{c}\text { Acar E, Dursun OB, } \\
\text { Esin İS, Öğütlü H, } \\
\text { Özcan H, } \\
\text { Mutlu M } \text { M }^{(45)}\end{array}$ & $\begin{array}{l}\text { Turkey } \\
2015\end{array}$ & $\begin{array}{c}\text { Case-control } \\
\text { study/ } \\
\mathrm{N}(\text { cases })=40 \\
\mathrm{~N}(\text { control })=40\end{array}$ & $\begin{array}{l}\text { To examine the relation } \\
\text { between home-based } \\
\text { injuries in children and } \\
\text { the presence of parents } \\
\text { with symptoms of } \\
\text { hyperactivity disorder } \\
\text { (ADHD). }\end{array}$ & $\begin{array}{l}\text { Intermediate SDH: (psychological factors). } \\
\text { AH were addressed in a general way. The risk of ADHD among } \\
\text { parents was significantly higher in children hospitalized for AH } \\
\text { compared to the control group. Having a father at high risk for } \\
\text { ADHD increased two times the relative risk of children being } \\
\text { exposed to injuries. }\end{array}$ & III 2 \\
\hline $\begin{array}{l}\text { Yamaoka Y, } \\
\text { Fujiwara T, } \\
\text { Tamiya } \mathrm{N}^{(46)}\end{array}$ & $\begin{array}{c}\text { Japan } \\
2016\end{array}$ & $\begin{array}{l}\text { Transversal } \\
\text { study with } \\
\text { descriptive } \\
\text { and analytical } \\
\text { components/ } \\
\mathrm{N}=6534\end{array}$ & $\begin{array}{l}\text { To investigate the } \\
\text { association between } \\
\text { unintentional injuries } \\
\text { in children and } \\
\text { postpartum depression. }\end{array}$ & $\begin{array}{l}\text { Intermediate SDH: (psychological factors). } \\
\text { General AH were addressed. 9.8\% of the infants suffered } \\
\text { unintentional injuries and } 9.5 \% \text { of the mothers had postpartum } \\
\text { depression. After adjustment for covariates, postpartum } \\
\text { depression was significantly associated positively with any } \\
\text { unintentional injuries. }\end{array}$ & III 3 \\
\hline $\begin{array}{l}\text { Stewart J, } \\
\text { Benford } \mathrm{P}, \\
\text { Wynn } \mathrm{P}, \\
\text { Watson } \mathrm{MC} \text {, } \\
\text { Coupland C, } \\
\text { Deave T, et al }{ }^{(47)}\end{array}$ & $\begin{array}{l}\text { United } \\
\text { Kingdom } \\
2016\end{array}$ & $\begin{array}{c}\text { Case-control/ } \\
\mathrm{N}(\text { cases })=338 \\
\mathrm{~N}(\text { control })= \\
1438\end{array}$ & $\begin{array}{l}\text { To determine the } \\
\text { relation between a } \\
\text { range of modifiable } \\
\text { risk factors and cases of } \\
\text { medically assisted burns } \\
\text { in children under } 5 \text {. }\end{array}$ & $\begin{array}{l}\text { Proximal SDH: (ethnicity/race). Distal SDH: (housing; economic } \\
\text { factors). } \\
\text { AH by Burns/Scaldings were addressed. The children of the } \\
\text { cases were slightly younger than the control ones (median age } \\
1.47 \text { vs. } 1.56 \text { years old), less likely to be of white ethnic origin } \\
\text { ( } 82 \% \text { vs. } 91 \% \text { ), more likely to receive state benefits ( } 46 \% \text { vs. } \\
35 \% \text { ) and greater probability of living in rented places ( } 50 \% \\
\text { vs. } 37 \% \text { ). In addition, they lived in neighborhoods with higher } \\
\text { deprivation scores (median, } 20.6 \text { vs. } 15.7 \text { ). }\end{array}$ & III 2 \\
\hline $\begin{array}{l}\text { Emond A, } \\
\text { Sheahan C, } \\
\text { Mytton J, } \\
\text { Hollén L }{ }^{(48)}\end{array}$ & $\begin{array}{l}\text { United } \\
\text { Kingdom } \\
2017\end{array}$ & $\begin{array}{l}\text { Cohort study/ } \\
\mathrm{N}=12.966\end{array}$ & $\begin{array}{l}\text { Investigate } \\
\text { behavioral and child } \\
\text { developmental } \\
\text { characteristics and the } \\
\text { risk of burns and scalds. }\end{array}$ & $\begin{array}{l}\text { Proximal SDH: (child's age; child's sex). Intermediate SDH: } \\
\text { (behavioral factors). } \\
\text { AH by Burns/Scaldings were addressed. Boys younger than two } \\
\text { years old were more likely to suffer burns, and girls suffered more } \\
\text { burns between five and eleven. Pre-school injuries were related } \\
\text { to gender and motor development, and in school-age children: } \\
\text { frequent tantrums, hyperactivity, and coordination difficulties. }\end{array}$ & III 2 \\
\hline
\end{tabular}

\section{DISCUSSION}

\section{Category 1 - Proximal Social Determinants of Health}

According to the level of comprehensiveness, individuals are based on the Dahlgren and Whitehead model, with individual characteristics of age, gender and genetic factors that, of course, influence their potential and health conditions ${ }^{(49)}$. In 22 analyzed articles the relation between Proximal SDHs and the occurrence of $\mathrm{AH}$ in childhood was investigated. The child's age was reported as capable of influencing the occurrence of $\mathrm{AH}$ in 16 analyzed articles, varying the prevalence among younger and older children depending on the type of $\mathrm{AH}$.

In studies involving $\mathrm{AH}$ in general, in which no type specification was made, a statistically significant association was observed between the frequency of $\mathrm{AH}$ that caused injuries and age groups $s^{(25,28,31,43)}$. The age group with the highest frequency is the group between four and five years old ${ }^{(31,43)}$. It is found that, in general, accidents are less frequent among children under one. In the context of the $\mathrm{AH}$ caused by a specific cause, the poisonings or intoxications were also analyzed from the age of the child in seven surveys ${ }^{(18,21,26-27,30,32,41)}$. The same analysis was performed in cases of accidental drowning/submersion injuries in childhood $^{(33)}$ and television falling on the child ${ }^{(37)}$. Following the same tendency of studies involving $\mathrm{AH}$ without specification, it is evident that the most prevalent age group in these occurrences varies from one to three years old ${ }^{(37)}$, and one to five years old ${ }^{(18,33)}$, with a variation of the mean age of $31.8^{(30)}$ to 36 months $^{(32)}$. The peak occurrence is usually between one and two years old ${ }^{(26-27,30)}$ and then decreasing to four years old ${ }^{(26)}$.

In this age group, there are intense changes related to the growth and development of mobility, cognitive ability and receptive comprehension, which may contribute to the occurrence of $\mathrm{AH}^{(1)}$. In addition, factors related to the child, such as age or stage of development, affect adult behavior, particularly supervision, an intermediate $\mathrm{SDH}^{(28)}$. It is identified that younger children are more supervised than older ones ${ }^{(25)}$. Parents are less likely to be present when accidents occur between the ages of two and four, and at that age, children tend to play more with their siblings, contributing to the occurrence of $\mathrm{AH}$ injuries ${ }^{(28)}$. 
In addition, children younger than one year are, in most cases, more supervised and therefore more protected, which can be evidenced by the fact that mothers who report providing more supervision have children who are less injured ${ }^{(25)}$.

In contrast, cases involving burns/scalding, evaluated in two studies, determined that the prevalence of injuries resulting from this type of $\mathrm{AH}$ was significantly higher in the period between birth and two years old compared to the age group between two and four years old and five and eleven years ${ }^{(40,48)}$. In the case of a burning injury, the greatest risk is between the ages of one and two years when compared to those under one year old and are especially associated with motor development ${ }^{(40)}$. Concerning the risk of asphyxia/strangulation/suffocation in bed, most deaths (71\%) occur before a baby reaches four months, with a mean age of 96 days $^{(38)}$.

The studies that evaluated SDH Sex among children who suffered $\mathrm{AH}$, either in the general context ${ }^{(19-20,22,25,28-29,31,42)}$ or in specific cases, such as poisoning or intoxication ${ }^{(18,21,26-28)}$, burn $^{(40,48)}$, drowning ${ }^{(33)}$, falls ${ }^{(35,37)}$ and asphyxia/strangulation/suffocation in bed $^{(38)}$ showed a higher ratio of males. Thus, it is possible to affirm that male sex is related to the occurrence of $\mathrm{AH}$ in childhood in all studies $^{(8)}$. In many cases, the difference in the occurrence of $\mathrm{AH}$ between the sexes is related to the proportion of time the child is supervised, with boys more often not supervised than girls(25), emphasizing once again the association between the proximal and intermediate SDH. In addition, the greater occurrence of accidents in boys can be attributed to activities and behaviors that are differentiated in both sexes and to cultural factors ${ }^{(22)}$, with greater exposure of boys to situations of risk, such as games with ball, bicycles, cycles, skateboards, among others ${ }^{(5)}$. Such correlation reveals an association between proximal and distal SDH.

Regarding the Proximal SDHs, as for the individual characteristics, six articles evaluated the children's ethnicity/race and their correlation with $\mathrm{AH}$ (in general ${ }^{(19,25,43)}$; asphyxiation/strangulation/ suffocation in bed ${ }^{(38)}$; burn $\left.{ }^{(48)}\right)$. In this context, white children were

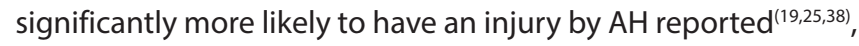
followed by Hispanic and black ethnicity ${ }^{(25,38)}$. Migrant children have been shown to be exposed to more domestic risks compared to local children ${ }^{(43)}$. In the specific area of $\mathrm{AH}$ involving burns, however, this situation is modified, with a higher prevalence among non-whites ${ }^{(47-48)}$. It is possible to state that there is a correlation between the Proximal SDH ethnicity/race and the Distal SHD cultural factors, since certain practices, in specific contexts, relate to the ways different liquids are heated when preparing beverages and foods to be offered to the child ${ }^{(47)}$.

\section{Category 2 - Intermediate Social Determinants of Health}

The articles that refer to the second category, "Intermediate Social Determinants of Health", discussed diverse topics. In 24 studies, the following factors were identified: behavioral (supervision); lifestyle (single-parent/biparental households); maternal age; psychological factors; and social and community networks.

Behavioral factors, especially those related to the lack of adult supervision, were identified in a large part of the articles analyz $\mathrm{ed}^{(18,23,25-26,28-33,36-37,39,41,43,48)}$. The main $\mathrm{AHs}$ that were related to this determinant were: intoxications; falls and burns $s^{(18,21,26,30,32,41,48)}$. In such contexts, direct adult supervision is one of the protective factors to prevent childhood accidents. This is because providing more attentive care to a vulnerable person enhances the early identification of risks and therefore helps to prevent accidents ${ }^{(50)}$. In some cases, this supervision is impaired due to the number of children in the family and the concomitant accomplishment of several housework by the responsible adult, the latter being a determining factor for accidental poisoning in childhood ${ }^{(32)}$. This analysis reveals an association between Intermediate SDH supervision and Distal SDH, especially maternal occupation.

Maternal age was also associated with the occurrence of these injuries, since daughters of younger mothers suffered more accidents $^{(20,22,31,36,38-40,44)}$. For children of mothers under 30, the risk of accidents was 1.9 times higher than for children of mothers over $30^{(31)}$. The relation between the age of parents and the occurrence of $\mathrm{AH}$ can be justified by the fact that older parents have more experience than younger ones and are more attentive to situations that give children the risk of accidents ${ }^{(22)}$.

Another AH-related factor was the family lifestyle, especially in those with many children or in whom there was only one responsible for the child (father or mother) ${ }^{(32,38-40,42)}$. This evidence may be related with high family stress caused by the excess of activities within the home context, leading to mental distraction of parents ${ }^{(43)}$. Thus, having a support network, such as friends and neighbors, can reduce the risk of unintentional injuries in children ${ }^{(36,39)}$. In this context, there is an association between different types of Intermediate SDH: lifestyle, psychological factors, maternal occupation and social networks.

The mental state of parents was also a conditioning factor for $\mathrm{AH}$. Mothers who present postpartum depression are less prone to more protective behaviors, which facilitates the occurrence of falls in children younger than four months ${ }^{(46)}$. In addition, the presence of some ADHD-related symptoms among parents, such as nervousness, impaired communication and lack of attention, make children more prone to injuries ${ }^{(45)}$.

\section{Category 3 - Distal Social Determinants of Health}

In the third theoretical category, "Distal Social Determinants of Health", 27 articles referred to aspects of living and working conditions, general socioeconomic, cultural and environmental conditions identified in the employment of the father/ mother $(18,20,22-23,30-31)$, housing ${ }^{(18-19,21-23,28-30,32-33,35-37,39,43,47)}$, access to health services ${ }^{(19,21-22,38)}$, cultural factors ${ }^{(18,28,30,41,43)}$, living conditions $^{(19-20,22-23,28,39-40,44)}$, social factors ${ }^{(18-19,22,26,36,39-40,42-43)}$, economic factors $^{(18-19,22-24,28,30,32,35-36,39-40,42-44,47)}$, environmental factors ${ }^{(33)}$, education $^{(24,29,34,42)}$ and basic sanitation ${ }^{(39)}$.

The predominance of Distal SDH among AH indicates the relation between the socioeconomic level and the risk of injuries; however, in other findings, it is evident that families with low and high financial income have a similar risk for $\mathrm{AH}$ involving children, so this is not an aspect that can be directly confirmed ${ }^{(44)}$.

Nevertheless, it is important to emphasize that housing-related characteristics, in which the child lives, such as small houses with few rooms, can influence the occurrence of these injuries by facilitating the crowding of people and the lack of attention on the part of adults ${ }^{(22)}$. Moreover, many of these environments are 
not safe for children, either because families do not have enough economic conditions to invest in preventive measures ${ }^{(35)}$ or because parents are unaware of risk situations ${ }^{(23)}$. In this context, there is again an association between different SDHs: housing, economic factors and education.

\section{Study limitations}

It is highlighted as a limitation of the study the non-inclusion of multiprofessional databases. For this review, three databases (Cinahl, Lilacs and Medline) were selected, which established a limiting factor, since the manuscripts that were not indexed could not be selected to make up the sample. In addition, it is indicated as limitations the non-inclusion of studies of the type review and the impossibility to consider in the discussion the great variety of contexts of origin of the reviewed articles.

\section{Contributions to the Nursing, Health or Public Policy fields}

The results presented in the study provide further information about the etiology of $\mathrm{AH}$ with children. When identifying the social determinants of health associated with these injuries, it is perceived that their prevention is not only the responsibility of parents and/or family, but of the community and the environment in which they live. Thus, primary health care plays a fundamental role in the prevention of these injuries, since it is the gateway of the Unified Health System and has a greater possibility of identifying the demands of individuals and their community. Knowledge of the associated social determinants of health may guide the development of new educational programs and activities that may intervene, mainly, in changeable determinants.

\section{CONCLUSION}

The analysis of the articles evidenced the complexity and the multifactorial nature of the occurrence of $\mathrm{AH}$ in childhood. The presence of different $\mathrm{SDH}$ in the same context of occurrence of $\mathrm{AH}$, whether belonging to the same category or coming from different categories, has been found to mutually reinforce the risks and hinder the implementation of preventive measures.

It has been observed that the Proximal and Intermediate SDH are those more statistically associated with the etiology of $\mathrm{AH}$. The age and sex of the child, identified as Proximal SDH, are the ones that most influence the occurrence and the type of accident. Among the intermediate determinants, the lack of supervision by an adult facilitates the occurrence of injuries, mainly related to poisonings and burns. Despite a significant number of studies inserted in the review, it is necessary to expand investigations about psychological factors (Intermediate SDH) and social and economic factors (Distal SDH), since it was not possible to consistently identify the mechanism of action of these determinants in the occurrence of childhood $\mathrm{AH}$.

The identification of the main SDH involved in unintentional injuries with children should be used to adopt protective measures, mainly directed to factors that are changeable, such as behavioral ones. It also reinforces the importance of investing in public policies that reduce social inequities and exposure to risks, considering the different contexts in which children are inserted.

\section{REFERENCES}

1. Ablewhite J, Peel I, McDaid L, Hawkins A, Goodenough T, Deave T et al. Parental perceptions of barriers and facilitators to preventing child unintentional injuries within the home: a qualitative study. BMC Public Health. 2015;15:280. doi: 10.1186/s12889-015-1547-2

2. Peden MM, Oyegbite K, Ozanne-Smith, Hyder AA, Branche C, Rahman AK, et al. (editors). World report on child injury prevention. Geneva: World Health Organization; 2008 [cited 2018 Nov 3]. 232 p. Available from: http://apps.who.int/iris/bitstream/ handle/10665/43851/9789241563574_eng.pdf;jsessionid=D603EF856393A207B10D9BD931FFE336?sequence=1

3. Rafai M, Mekaoui N, Chouaib N, Bakkali H, Belyamani L, Koraichi A et al. Épidémiologie des accidents domestiques graves de l'enfant admis en réanimation pédiatrique polyvalente à l'hôpital d'enfants de Rabat-Maroc. Pan Afr Med J. 2015;20:28. doi:10.11604/pamj.2015.20.28.5760

4. Araújo EC. [Domestic accidents in children]. J Nurs UFPE Online [Internet]. 2016 [Cited 20 Feb 2017]; 10(Supl 3). Available from: https://doi. org/10.5205/1981-8963-v10i3a11073p\%25p-2016. Portuguese.

5. Malta DC, Mascarenhas MDM, Neves ACM, Silva MA. [Treatment of childhood injuries and violence in public emergency services]. Cad Saúde Pública [Internet]. 2015 [Cited 2017 July 20]; 31(5):1095-105. Available from: https://doi.org/10.1590/0102-311X00068814 Portuguese.

6. Pedrosa AAG, Mascarenhas MDM, Costa EM, Cronemberger LP. [Medical care due to accidental causes in emergency public services Teresina, Piauí - 2009]. Cien Saúde Colet [Internet]. 2012 [Cited 2017 July 10];17(9):2269-78. Available from: http://dx.doi.org/10.1590/ S1413-81232012000900009 Portuguese.

7. Martins CBG, Mello-Jorge MHP. Circumstances and factors associated with accidental deaths among children, adolescents and young adults in Cuiaba, Brazil. Sao Paulo Med J [Internet]. 2013 [Cited 2017 July 25]; 131(4):228-37. Available from: http://dx.doi. org/10.1590/1516-3180.2013.1314459

8. Kickbusch I. [Addressing the commercial determinants is critical to emerging economies]. Cien Saúde Colet [Internet]. 2015 [Cited 2017 Apr 30]; 20(4):628-29. Available from: http://dx.doi.org/10.1590/1413-81232015204.19962014

9. Sant'anna CF, Cezar-Vaz MR, Cardoso LS, Erdmann AL, Soares JFS. [Social determinants of health: community features and nurse work in the family health care]. Rev Gaúcha Enferm [Internet]. 2010 [Cited 2017 Feb 30]; 31(1):92-9. Available from: http://dx.doi.org/10.1590/S198314472010000100013 Portuguese. 
10. Imamura JH, Troster EJ, Oliveira CAC. What types of unintentional injuries kill our children? Do infants die of the same types of injuries? A systematic review. Clinics [Internet]. 2012 [Cited 2017 Feb 30]; 67(9):1107-16. Available from: http://dx.doi.org/10.6061/clinics/2012(09)20

11. Whittemore R, Knafl K. The integrative review: updated methodology. J Adv Nurs.2005;52(5):546-53. doi:10.1111/j.1365-2648.2005.03621.x

12. Karino ME, Felli VEA. [Evidence-based nursing: advances and innovations in systematic reviews]. Cien Cuid Saúde [Internet]. 2012 [Cited 2018 Apr 01];11(Supl):11-5. Available from: http://dx.doi.org/10.4025/cienccuidsaude.v11i5.17048 Portuguese.

13. Moher D, Liberati A, Tetzlaff J, Altman DG; PRISMA Group. Preferred reporting items for systematic review sand meta-analyses: the PRISMA statement. Ann Intern Med. 2009;151:264-9, W64.

14. Ursi ES, Gavão CM. [Perioperative prevention of skin injury: an integrative literature review]. Rev Lat Am Enfermagem [Internet]. 2006 [cited 2018 Nov 02]; 14(1):124-31. Available from: http://www.scielo.br/pdf/rlae/v14n1/v14n1a17.pdf Portuguese.

15. Presidência da República (BR), Casa Civil, Subchefia para Assuntos Jurídicos. Lei n. 8.069, de 13 de julho de 1990. Dispõe sobre o Estatuto da Criança e do Adolescentes e dá outras providências [Internet]. Diário Oficial da União: República Federativa do Brasil; 1990. [Cited 2018 Nov 3]. !3 Jun, Seção 1: 48 p. Available from: http://www.planalto.gov.br/CCivil_03/Leis/L8069.htm

16. Buss PM, Pellegrini Filho A. [Health and its social determinants]. Physis [Internet]. 2007 [Cited 2017 Jan 10]; 17(1):77-93. Available from: http://dx.doi.org/10.1590/S0103-73312007000100006 Portuguese.

17. Ministério da Saúde (BR), Secretaria de Atenção à Saúde, Departamento de Atenção Básica. Saúde da criança: crescimento e desenvolvimento [Internet]. Brasília: Ministério da Saúde; 2012 [Cited 2018 Nov 3]. Cadernos de Atenção Básica, n. 33.272 p. Available from: http://bvsms.saude.gov.br/bvs/publicacoes/saude_crianca_crescimento_desenvolvimento.pdf

18. Mahdi AH, Taha AS, AI Rifai MR. Epidemiology of accidental home poisoning in Riyadh (Saudi Arabia). J Epidemiol Community Health [Internet]. 1983 [Cited 2017 Feb 30]; 37(4):291-5. Available from: https://www.ncbi.nlm.nih.gov/pmc/articles/PMC1052927/

19. Mott JA. Personal and family predictors of children's medically attended injuries that occurred in the home. Inj Prev. 1999; 5(3):189-93.

20. Ramsay LJ, Moreton G, Gorman DR, Blake E, Goh D, Elton RA et al. Unintentional home injury in preschool-aged children: looking for the key - an exploration of the inter-relationship and relative importance of potential risk factors. Public Health [Internet]. 2003 [Cited 2017 Apr 30]; 117(6):404-11. Available from: https://doi.org/10.1016/S0033-3506(03)00072-6

21. Ramos CLJ, Targa MBM, Stein AT. [Caseload of poisoning among children treated by the Rio Grande do Sul State Toxicology Information Center (CIT/RS), Brazil]. Cad Saúde Pública [Internet]. 2005 [Cited 2016 Dec 10];21(4):1134-41. Available from: http://www.scielo.br/pdf/csp/ v21n4/15.pdf Portuguese.

22. Lima RP, Ximenes LB, Vieira LJES, Oriá MOB. [Profile of children's families afflicted by an accident in the domiciliary context]. Online Braz J Nurs [Internet]. 2006 [Cited 2017 Apr 10]; 5(3). Available from: http://www.objnursing.uff.br/index.php/nursing/article/view/386/89 Portuguese.

23. Moreira BFC, Vieira LJES, Oriá MOB, Ximenes LB, Almeida PC. [Risk factor for burns and electric shock in children in the domestic setting]. REME Rev Min Enferm [Internet]. 2008 [Cited 2017 Apr 20]; 12(1):86-91. Available from: http://www.dx.doi.org/S1415-27622008000100012 Portuguese.

24. Liyanage IK, Pathirana AC, Wickramasinghe KK, Karunathilake IM, Olupaliyawa A. A study of risk factors for non-intentional domestic injuries among preschoolers in three suburban areas of Sri Lanka. Asia Pac J Public Health. 2008;20(Suppl):156-61.

25. Morrongiello BA; Klemencic N, Corbett M. Interactions between child behaviour patterns and parent supervision: implications for children's risk of unintentional injury. Child Dev. 2008;79(3):627-38. doi: 10.1111/j.1467-8624.2008.01147.x

26. Schmertmann M, Williamson A, Black D. Stable age pattern supports role of development in unintentional childhood poisoning. Inj Prev. 2008;14(1):30-3. doi: 10.1136/ip.2007.016253

27. Belonwu RO, Adeleke SI. A seven-year review of accidental kerosene poisoning in children at Aminu Kano Teaching Hospital, Kano. Niger J Med. 2008;17(4):380-2.

28. Simpson JC, Turnbull BL, Ardagh M, Richardson S. Child home injury prevention: understanding the context of unintentional injuries to preschool children. Int J Inj Contr Saf Promot. 2009;16(3):159-67. doi: 10.1080/17457300903135636

29. Morrongiello BA, Corbett M, Brison RJ. Identifying predictors of medically-attended injuries to young children: Do child or parent behavioural attributes matter? Inj Prev. 2009;15(4):220-5. doi: 10.1136/ip.2008.019976

30. Ramos CL, Barros HM, Stein AT, Costa JS. [Risk factors contributing to childhood poisoning]. J Pediatr (Rio J) [Internet]. 2010 [Cited 2017 Apr 11];86(5):435-40. Available from: https://doi:10.2223/JPED.2033 Portuguese.

31. Atak N, Karaoğlu L, Korkmaz Y, Usubütün S. A household survey: unintentional injury frequency and related factors among children under five years in Malatya. Turk J Pediatr. 2010;52(3):285-93.

32. Manzar N, Saad SM, Manzar B, Fatima SS. The study of etiological and demographic characteristics of acute household accidental poisoning in children - A consecutive case series study from Pakistan. BMC Pediatr. 2010;10:28. doi: 10.1186/1471-2431-10-28

33. Shields BJ, Pollack-Nelson C, Smith GA. Pediatric submersion events in portable above-ground pools in the United States, 2001-2009. Pediatrics.. 2011;128(1):45-52. doi: 10.1542/peds.2010-3033

34. Carlsson A, Bramhagen AC, Jansson A, Dykes AK. Precautions taken by mothers to prevent burn and scald injuries to young children at home: an intervention study. Scand J Public Health. 2011;39(5):471-8. doi: 10.1177/1403494811405094 
35. Johnston BD, Quistberg DA, Shandro JR, Partridge RL, Song HR, Ebel BE. Pilot case-control study of paediatric falls from windows. Inj Prev.. 2011;17(6):375-80. doi: 10.1136/ip.2010.030395

36. Pearce A, Li L, Abbas J, Ferguson B, Graham H, Law C. Does the home environment influence inequalities in unintentional injury in early childhood? Findings from the UK millennium cohort study. J Epidemiol Community Health. 201;66(2):181-8. doi: 10.1136/jech.2011.139626

37. Güloğlu R, Sarıcı IS, Bademler S, Emirikçi S, Işsever H, Yanar H et al. Falling television related child injuries in Turkey: 10-year experience. Ulus Travma Acil Cerrahi Derg. 2012;18(1):61-4. doi: 10.5505/tjtes.2011.54775

38. Carlberg MM, Shapiro-Mendoza CK, Goodman M. Maternal and infant characteristics associated with accidental suffocation and strangulation in bed in US infants. Matern Child Health J. 2012 16(8):1594-601. doi: 10.1007/s10995-011-0855-0

39. Vieira LJEDS, Pordeus AMJ, Lira SVG, Moreira DP, Pereira ADS, Barbosa IL. Associated factors for the occurrence of unintentional injuries in children from a low-income community in northeastern Brazil. Acta Sci, Health Sci. 2012;34(2):127-35. doi: 10.4025/actascihealthsci. v34i2.10313

40. Shah M, Orton E, Tata LJ, Gomes C, Kendrick D. Risk factors for scald injury in children under 5 years of age: a case-control study using routinely collected data. Burns. 2013;39(7):1474-8. doi: 10.1016/j.burns.2013.03.022

41. Sheikh S, Chang A, Kieszak S, Law R, Bennett HKW, Ernst E et al. Characterizing risk factors for pediatric lamp oil product exposures. Clin Toxicol (Phila) .2013;51(9):871-8. doi: 10.3109/15563650.2013.839028

42. Kamal NN. Home unintentional non-fatal injury among children under 5 years of age in a rural area, El Minia Governorate, Egypt. J Community Health. 2013;38(5):873-9. doi: 10.1007/s10900-013-9692-y

43. Qiu X, Wacharasin C, Deoisres W, Yu J, Zheng Q. Characteristics and predictors of home injury hazards among toddlers in Wenzhou, China: a community-based cross-sectional study. BMC Public Health [Internet]. 2014[Cited 2017 Feb 11]; 14:638. Available from: https://doi. org/10.1186/1471-2458-14-638

44. Mayes S, Roberts MC, Stough CO. Risk for household safety hazards: Socioeconomic and sociodemographic factors. J Safety Res. 2014;51:8792. doi: 10.1016/j.jsr.2014.09.002

45. Acar E, Dursun OB, Esin İ, Öğütlü H, Özcan H, Mutlu M. Unintentional Injuries in Preschool Age Children: Is There a Correlation With Parenting Style and Parental Attention Deficit and Hyperactivity Symptoms. Medicine (Baltimore). 2015;94(32):e1378. doi: 10.1097/ MD.0000000000001378

46. Yamaoka Y, Fujiwara T, Tamiya N. Association Between Maternal Postpartum Depression and Unintentional Injury Among 4-Month-Old Infants in Japan. Matern Child Health J. 2016;20(2):326-36. doi: 10.1007/s10995-015-1832-9

47. Stewart J, Benford P, Wynn P, Watson MC, Coupland C, Deave T, et al. Modifiable risk factors for scald injury in children under 5 years of age: A Multi-centre Case-Control Study. Burns. 2016; 42(8):1831-43. doi: 10.1016/j.burns.2016.06.027

48. Emond A, Sheahan C, Mytton J, Hollén L. Developmental and behavioural associations of burns and scalds in children: a prospective population-based study. Arch Dis Child. 2017;102(5):428-83. doi: 10.1136/archdischild-2016-311644

49. Comissão Nacional Sobre Determinantes Sociais Da Saúde. As causas sociais das iniquidades em saúde no Brasil. Relatório Final da Comissão Nacional sobre Determinantes Sociais da Saúde (CNDSS). Rio de Janeiro: Fiocruz; 2008. 216 p.

50. Bezerra MAR, Santos LR, Rocha RC, Rocha SS, Brito ECC, Santos JP. [Perceptions that caregivers of children under five years of age have on the prevention of domestic accidents]. REME Rev Min Enferm [Internet]. 2016 [Cited 2017 Feb 11];20:e944. Available from: doi: 10.5935/1415-2762.20160014 Portuguese. 